\title{
Indeterminacy in Postmodern Fiction
}

\author{
Li Ma \\ School of Foreign Languages, Dalian University of Technology, Dalian, China
}

\begin{abstract}
Indeterminacy is an intrinsic feature of postmodern fiction. This paper focuses on the indeterminate feature of postmodern fiction, which refers to a complex category that is composed of various different concepts such as ambiguity, discontinuity, heterodoxy, pluralism, randomness, revolt, perversion and deformation etc. After a brief review of postmodernism and postmodern fiction, the paper explores the feature of indeterminacy embodied in the theme, plot, characters, language of postmodern fiction.
\end{abstract}

Index Terms - indeterminacy, postmodernism, postmodern fiction

\section{POSTMODERNISM}

Postmodernism is a hot topic in a wide variety of disciplines or areas of study, including art, architecture, music, film, literature, sociology, communications, fashion, and technology. Although a conceptual term is expected to have a clearcut definition that defines its connotation and extension, it is hardly so in the area of social science and humanities. The reasons are as follows: first of all, concepts in social science and humanities are relative, because unlike a concept in physical science that has an objective signified, the signified of a concept in social science and humanities is usually an idea that is scarcely definable; Secondly, since there are differences in their comprehension of the same concept, people constantly revise or redefine the concept only to enlarge its connotation rather than making it clearer and more exact. Postmodernism focused on in this thesis is an indefinable term of the sort.

Of all the definitions available, some scholars believe that postmodernism refers to a movement, for example, as Sarup (1993, p.131) understands, it is "a movement in advanced capitalist culture, particularly in the arts", while some others, like Murfin (2003, p. 297) take it as "certain radically experimental works of literature and art". No matter what else it may be, this thesis adopts that postmodernism is a cultural phenomenon embodied in areas such as art, literature and so on, which is becoming increasingly dominant in contemporary society.

As to the exact time when postmodernism arose, a unanimous agreement has not yet been reached among theorists since each of them sticks to his own viewpoint. These viewpoints can be generally sorted out into three catalogues, namely Genesis of Postmodernism before WWII Genesis of Postmodernism after WWII and Genesis of Postmodernism both before and after WII.

Theorists who hold that postmodernism originated before the Second World War are best represented by British postmodernist Charles Jencks and American postmodernist Ihab Hassan. Hassan indicates in his The Postmodern Turn (1987) that "postmodernism" might be traced back to the Spanish "Postmodernismo" in Federico De Onis's Antología de la poesía española e hispanoamericana published in 1934, and he believes that it is James Joyce's Finnegans Wake (1939) that marks the beginning of postmodernism. Jencks's view is slightly different from that of Hassan's because according to his research, he holds that it was British artist John Watkins Chapman who first put the term "postmodernism" to use in the 1870s, and that the appearance of term "post-industrial" in the sociology circle during the period from 1914 to 1922 marked the beginning of "Posties" researches. (Tong, 2003)

Theorists who believe that postmodernism came out after WWII have not reached a universal agreement either. American New Marxist scholar Fredric Jameson (1983) believes that postmodernism arose in the 1950s as the offspring of Transitional Capitalism, Late Capitalism and Consumer Society. American sociologist Daniel Bell (1976) holds that postmodernism prevailed in the 1960s as the result of modernism being pushed to an extreme by capitalist cultural conflicts. Still another chief postmodernist is French philosopher Jean-Francois Lyotard. His attitude (Lyotard, 2002) towards the origin of postmodernism is that it emerged in the 1960s as the result of information age as well as the reflection to the crisis of legalizing capitalism. So it easily comes to a conclusion that theorists who support that postmodernism firstly appeared after WWII generally associate the genesis of postmodernism with the development of capitalism and the crisis and conflicts in society after the Second World War, focusing on the research of the relationship among them.

Among those who advocate the Genesis of Postmodernism is both before and after WWII, Dutch scholar Hans Bertens is of chief importance. In his article "The Postmodern Weltanschauung and its Relation with Modernism: An Introductory Survey" included in Approaching Postmodernism (Bertens, 1986), he expounded the evolvement of postmodernism and defined it as the following four stages. The first period ranged from 1934 to 1964, during which postmodernism started to appear in literary works of many well-known writers such as Onis, Dudley Fitts etc. In the second phase of the middle 1960s, postmodernism interacted with the American anti-culture movement and postmodernists including Fiedler, Sontag and Wasson etc. made up their mind to break thoroughly with modern writers. During the third stage from 1972 to 1976, postmodernism developed into an international movement in which the 
European Existentialism had exerted its huge effect. At its last stage of development from the late 1970s to the 1980s, postmodernism was much more compatible because it adopted the various cultural phenomena that had not been accepted by modernism. (Tong, 2003)

Of the three theories of the origin of postmodernism, a comprehensive view is adopted in this thesis. Although scholars disagree as to who originally coined the term, there is a general consensus that postmodernism likely first appeared sometime in the 1930s referring to a major historical transition already under way and as the designation for certain developments in the arts. But postmodernism did not gain widespread attention until the 1970s, during which the postmodern challenge to modernism infiltrated into mainstream culture. At the beginning it denoted a new style of architecture, and then it invaded academic circles, originally as a label for theories expounded in college English and philosophy departments. Eventually it surfaced as the description for a much broader cultural phenomenon including literature, art and architecture, and other forms of thinking and expression. No matter what else it might possibly be, as the name suggests, postmodernism signifies the quest to move beyond modernism. Specifically, it involves a rejection of the modern mind-set, but launches under the conditions of modernism. Hence, to understand postmodern thinking, we have to view it in the context of the modern world that gave birth to it and against which it is reacting. (Grenz, 1996)

Modernism, as defined in The Bedford Glossary of Critical and Literary Terms, is a revolutionary movement including all of the creative arts that rooted in the 1890s, and a transitional period during which artists and writers sought to liberate themselves from the constraints and polite conventions associated with Victorianism. (Murfin, 2003) Modernists endeavor to break away from traditions and conventions through experimentation with new forms, devices, and styles, and modern works reflect the pervasive sense of loss, disillusionment, and even despair in the wake of the First World War.

With the affix "post-", postmodernism suggests a time after modernism, or the future of modernism, so postmodernism follows modernism as both a succession and an anti of it.

On the one hand, modernism creates the conditions from which postmodernism grows, and postmodernism arises partly as a continuation of some modern ideas such as challenging cultural forms and pushing back the limits of how people represent the world. Take literature as an example, postmodern literature preserves some writing techniques, the spirit and even some of the themes of modern literature such as the alienation of humanity, historical discontinuity and so on. In this aspect, modernism and postmodernism interwind with each other and there is no strict boundary that distinguishes them.

On the other hand however, postmodernism resists the modernist doctrine of the supremacy of reason, the notion of truth, and the belief in the perfectibility of man. Although scholars disagree among themselves as to what explicitly postmodernism involves, they have reached a consensus on one point: this phenomenon marks the end of a single, universal worldview. Postmodernism abandons the quest for a unified grasp of objective reality, and it asserts that the world has no center, only differing viewpoints and perspectives. The postmodern ethos resists unified and universally valid explanations advocated by modernism. It replaces them with a respect for difference and a celebration of the local and particular at the expense of the universal. Postmodernism also entails a rejection of the emphasis on rational discovery through the scientific method, which has provided the intellectual foundation for the modern attempt to construct a better world. As its foundation, then, the postmodern outlook is anti-modern.

\section{INDETERMINACY IN POSTMODERN FICTION}

E. M. Foster talked about all sorts of aspects of fiction in his The Art of Fiction in 1927, but his days are far earlier than the time in which postmodern fiction exploded onto the international scene. As it is no easy job to define fiction, it is even harder to define postmodern fiction. The modifier "postmodern" is complicating rather than simplifying the definition of postmodern fiction. If it serves as a time determiner, postmodern fiction becomes fiction in postmodern age, which involves all the fiction after the 1970s. It is obviously imprecise because on the one hand, some novels with postmodern features were not produced during that period, such as Miguel de Cervantes's Don Quixote written in the $17^{\text {th }} \mathrm{C}$ and Laurence Sterne's Tristram Shandy produced in the $19^{\text {th }} \mathrm{C}$, while on the other hand, novels composed after the 1970s are not necessarily all postmodern. Realistic, romantic or other genre of fiction also came out during the period from the 1960s to the 1970s in which postmodern fiction was flourishing. Therefore, postmodern fiction here does not refer to novels composed after the 1970 s but those with postmodern literary features.

\section{A. Origin and Development of Postmodern Fiction}

Although postmodern fiction might be traced back as early as to the $17^{\text {th }} \mathrm{C}$ or even earlier, most western critics believe that it became an influential literary trend in around the 1950s and the 1960s in Britain and the U.S., and after reached its peak in the 1970s and the 1980s it faded in the 1990s. Postmodern fiction was born and developed under certain historical and cultural background. A comparatively general understanding is that it is the direct result of the western turbulent social life after the Second World War. People were so shocked by the fascists' appalling ferocity during WWII that they started to doubt the social moral standard and values they had been holding all along. After the war, as the intrinsic problems in capitalistic society became more conflicting, people were more and more confused with the increase of social upheavals and they lost faith and loyalty, and became indifferent to others. 
Such disorder of society cannot be separated from the rapid development of science and technology, which turns the society into an accurate machine on which each person serves as a trivial part. Mass media and convenient transportation broaden the public knowledge and people start to realize that the existence of knowledge and objects depend on themselves and the relation between them, rather than certain eternal nature. Meanwhile, the development of high-tech brings about mechanical and digital copies in large scale, hence reality and original texts disappear and everything can be fake and imitation. Modern societies are constructed on the basis that signifiers always point to signifieds in which reality resides, while in postmodernism, however, there are only signifiers. The idea of any stable or permanent reality disappears, and gone with it the idea of signifieds that signifiers point to. In literary field, "The fiction of the creating subject gives way to the frank confiscation, quotation, accumulation and repetition of already existing images. Works such as these which bring together heterogeneous images and technologies not only undermine many modernist assumptions but also raise questions about originality and authenticity." (Sarup, 1993, p.173) Intertexuality and hypertexts take the place of manuscript and originality and the world becomes an unknowable indeterminacy.

Compared with modern fiction, postmodern fiction challenges and disintegrates the form of fiction itself, rather than innovate it. Modern fiction emphasizes skills, structure and language, while postmodern works blur literary genres and break conventional narration. In contrast to the absurd meanings in modern fiction, postmodern fiction is meaningless with language games. Unlike the modern writing skills such as interior monologue and stream-of-consciousness, postmodern skills include irony, pastiche and collage etc.

\section{B. Indeterminacy as a Significant Feature of Postmodern Fiction}

Postmodern fiction cannot be easily confined to a concrete definition; however, most postmodern works share some common features, such as plurality, centerlessness, language experiment and language game etc. These features generally fall into the principal character of indeterminacy. British postmodernist David Lodge (1986) believes that postmodernism exceeds and sublates modernism with its negative sense, and that postmodernism attacks the pursuit of determinacy of rationalism, holding indeterminacy as its intrinsic feature. Postmodern novelists think that there is no apriority or objectivity in meaning since everything is uncertain, centerless and incoherent. Indeterminacy as the essence of postmodernism is not only a mode to appreciate the essence of postmodern life, but also a writing technique.

As one of the literary critics who first apply the concept of "postmodern", Ihab Hassan coined the term "indeterminacy" in his The Postmodern Turn: Essays in Postmodern, Theory and Culture in 1987 referring to a complex category that is composed of various different concepts. It includes the concepts of ambiguity, discontinuity, heterodoxy, pluralism, randomness, revolt, perversion and deformation etc., all of which represent the postmodernists' universal will to abandon everything. (Tong, 2003) Widely used in areas of postmodern architecture, painting, literature, music, and politics, the physical and biological sciences and so on, the term affects the western political system, the public cognitive system and mentality. As to indeterminacy in postmodern literature, concepts of authors, readers, reading, literary schools, critical theories, and even the concept of literature itself are challenged when Roland Barthes announced the "Death of the Author" and Geoffrey Harman asserted that the purpose of contemporary criticism lies in the hermeneutics of indeterminacy. (Hassan, 1987) Indeterminacy in postmodern fiction is reflected in the following aspects.

\section{Indeterminacy in the Theme}

Realist writers emphasize the themes of their works, while modernists oppose to themes of realist works rather than theme itself. As to postmodern novelists, they abandon themes in their literary creation, because there is no meaning, center, or essence in postmodern works. Everything in postmodern fiction is on the same level so that no theme or subheading or even a topic is needed, and writers' attention is paid to the randomness, extemporization and collage during the creative process of postmodern production.

After Nietze announced God's death in the late 1880s, French theorist Roland Barthes followed suit and published his article "The Death of the Author" in 1981, which placed great emphasis on importance of readers' participation and cooperation in novel creation. Previous literary creation stresses the author's dominance in the production so a novel is completed as soon as it is composed by its writer and readers will have to passively accept it. As postmodern fictionists believe, the work created by a writer is half done, and the other half is to be finished through reading and imagination of the readers. Therefore, closed texts are opened by postmodern novelists and the previously advocated explicit works are indeterminate with postmodernism. Themes designed by authors thus "die" with them, and the meaning of fiction depends on the understanding of each reader.

\section{Indeterminacy in the Character}

Since postmodernists believe in the death of subject and author, characters in literary works naturally die with them; therefore in postmodern literary works characters are vague figures or even images. For example, in the novelle "Sindbad" in Forty Stories (1987) by the American postmodern novelist Donald Barthelme, there are two protagonists: one is the skillful sailor Sindbad and the other is "I", a teacher in the 1980s America. Poor and dowdily dressed, "I" am looked down upon by my students, so when "I" enthusiastically encourage them to "Be like Sindbad! Venture forth..." (p.24), the students simply respond that there is nothing outside. When "I" retort that there is waltz, sword and dazzling floating seaweed, the waltz here refers to the previously mentioned melody that guides Sindbad to the forest after his eighth navigation wrecking. Here it is hard for readers to figure out whether it is teacher "I" or sailor Sindbad that is speaking. How many characters are there in this short story, one or two? What is the relationship between Sindbad and 
"I'? Maybe they are friends who know each other, or maybe Sindbad retires to be a teacher and they two are the same person. The specious images dispel any attempt at making out determinate meanings; hence readers are free to use their own intelligence and to appreciate the postmodern indeterminacy.

Characters depicted by postmodernists are usually images or symbols that lack ontic determinacy despite their human characteristics. In their works, postmodern authors either profess or imply that characters are artificiality constructed by letters; therefore they are being-there instead of being-in-the-world. (Hu, 2000) Characters in postmodern novels do not actually exist, but appear as ideas, so they are unknowable to readers. In contrast to characters in realistic novels that can stay vividly in readers' mind, postmodern characters are vague and indeterminate. In another typical postmodern fiction $V$ (1963) by Thomas Pynchon, the disordered narration fragments confuse readers in terms of what on earth the letter "V" stands for. The "V" being searched for by Stencil is indeterminate of its identity, and its entity is even vague to the author himself as he states in the fiction that "There is more behind and inside V than any of us had suspected. Not who, but what: what is she" (p.53). It seems that "V" refers to a female, but is she a real figure in the protagonist's life or is she simply his fantasy? The answer cannot be traced in this postmodern novel, and readers have to depend on their own intelligence and endow the characters with some real meanings.

\section{Indeterminacy in the Plot}

Postmodern fictionists oppose to logic, coherence, and closeness in plot arrangement and they believe that close structure that has coherent meaning, characters' logical movements and integrated plot is merely writers' own wishful thinking, instead of something based on real life. So such a close structure should be broken and replaced by an open framework, and postmodern writers abandon logic and coherence during the process of novel creation only to permute historical time, present time and future time. With past, present and future randomly reversed and space constantly divided and severed, there arise various infinite possibilities in plot of postmodern literary works.

Donald Barthelme's short story "The Explanation" in Forty Sotries (1987) is structured with an open plot and the skill of juxtaposing multi-closures. At the beginning, four hollow panes introduce a series of questions and answers that develop into closures of all sorts. Bounds of time or space are thoroughly broken since there is no evidence in the fiction that hint the time when or place where the dialogues take place. The conversations between the unknown speakers are themeless and the topics involving various aspects of postmodern life range from literature to arts, love, trees, books, narrative strategies or to travel, football matches etc. Traditional story mode of outset, complex, climax and denouement is abandoned in this novel and its plot is arranged randomly as a postmodern uncertainty.

\section{Indeterminacy in the Language}

Austrian philosopher Ludwig Wittgenstein is a significant figure who contributes to the reconstruction of the nature of language. He believes (Wittgenstein, 1961, p.39) that language "pictures" the world, and he asserts that "each use of language occurs within a separate and apparently self-contained system complete with its own rules". In this sense, the use of language is similar to playing a game and each use of language constitutes a separate "language game" (Grenz, 1996, p.113). Holding the notion of language as a game, postmodernists aim at dispelling reality and creating a new world with the sole tool of language. They do not take up the responsibility of reflecting a real world; instead, they regard novel creation itself as reality and construct a disordered world with words. In the postmodern classic $V$ mentioned previously, the language game reaches its peak through the use of the mysterious letter "V". It may stand for the female character Victoria, or any of the other characters in the fiction whose names start with the letter "V". It may also refer to the series of "V"-started appellations including a country, a street, an article and so on. Pynchon is playing language game with readers, so the world of "V", as well as the language in this fiction, becomes indeterminate.

To adopt the concept of "language game" is to take an important step toward rejecting the idea of objective reality. In his later works, Wittgenstein explicitly abandons the concept of truth as correspondence with reality or a picturing of reality, characterizing it instead as an internal function of language. No proposition can be limited to a single meaning, he believes, because its meaning is necessarily dependent on its context, and the language game in which it is involved. Thus, every sentence has as many meanings as the number of contexts in which it is applied. Taken to its logical conclusion, as Grenz (1996) put it, this position implies that one can never claim to be stating the final truth or truth in any ultimate sense; at most, he can produce utterances that are true within the context in which they are spoken.

Postmodern novels indicate a thorough reconstruction and innovation of arts' mode, as well as a tremendous chaos and anarchy of novel creation. Although it is not the sole trend of the late $20^{\text {th }} \mathrm{C}$ western literary world, or even not the mainstream, its effect on the development of the world literature, as well as its contribution to the innovation of literary notions is significant.

\section{CONCLUSION}

Involving all the acts that may exert influence on knowledge and ambiguities, ruptures and displacements of society, indeterminacy has always been a typical and significant feature of postmodern writing. It brings each and every existence into skepticism that permeates through our actions and thinking only to construct the world we are living in. Overthrowing authorial authoritative legacy, indeterminacy in postmodern literature advocates a revolt to traditional writing styles, such as a definite theme or meaning, integrated plot of a story and so on. 
The research was supported by the Fundamental Research Funds for the Central Universities (No. DUT13RW420).

\section{REFERENCES}

[1] Barthelme, D. (1987). Forty Stories. New York: GP Putnam's Sons.

[2] Bell, D. (1976). The Cultural Contradictions of Capitalism. New York: Basic Books.

[3] Bertens, H. (1986). The Postmodern Weltanschauung and its Relation with Modernism: An Introductory Survey. In Fokkema, D. W. \& Bertens, J. W. (eds.), Approaching Postmodernism: Papers Presented at a Workshop on Postmodernism. Utrecht: University of Utrecht, 9-52.

[4] Grenz, S. J. (1996). A Primer on Postmodernism. Grand Rapids: Wm. B. Eerdmans Publishing Co.

[5] Hassan, I. (1987). The Postmodern Turn: Essays in Postmodern Theory and Culture. Ohio: The Ohio State University Press.

[6] Hu, Q. (2000). Characters and Characterization of Postmodern Fiction. Journal of Foreign Languages, 4, 52-58.

[7] Jameson, F. (1983). "Postmodernism and Consumer Society". In Foster, H. (eds.), The Anti-Aesthetic: Essays on Postmodern Culture. Seattle: Bay Press, 111-125.

[8] Lodge, D. (1986). Working with Structuralism: Essays and Reviews on Nineteenth and Twentieth Century Literature. London: Cox and Wyman Ltd.

[9] Lyotard, Jean-Francois (2002). The Postmodern Condition: A Report on Knowledge. Minneapolis: The University of Minnesota Press.

[10] Murfin, R. \& Ray, S. M. (2003). The Bedford Glossary of Critical and Literary Terms. Boston: Bedford/St. Martin's.

[11] Pynchon, T. (1963). V. New York: Bantam Books.

[12] Sarup, M. (1993). An Introductory Guide to Post-Structuralism and Postmodernism. Athens: The University of Georgia Press.

[13] Tong, L. (2003) Research on the Philosophical Trends of Western Postmodernism. Tianjin: Tianjin People's Publishing House.

[14] Wittgenstein, L. (1961). Tractatus Logico-Philosophicus, trans. Pears, D. F. \& McGuinness, B. F. London: Routledge \& Kegan Paul.

Li Ma, M.A., is a lecturer in the School of Foreign Languages, Dalian University of Technology. Her major research interests include English and American postmodern literature, postmodern philosophy of culture, and teaching of English in Chinese EFL context. 